\title{
THE ACUTE EFFECTS IN MAN OF A RAPID INTRAVENOUS INFUSION OF HYPERTONIC SODIUM BICARBONATE SOLUTION. II. CHANGES IN RESPIRATION AND OUTPUT OF CARBON DIOXIDE ${ }^{1}$
}

\author{
By R. B. SINGER, ${ }^{2}$ R. C. DEERING, ${ }^{3}$ AND J. K. CLARK \\ (From the Departments of Research Medicine, Biochemistry, and Physiology, and the Renal \\ Section of the Department of Medicine, The University of Pennsylvania, \\ Philadelphia, $P a$.)
}

(Submitted for publication December 1, 1954; accepted October 10, 1955)

It is generally agreed that in metabolic acidosis respiration is stimulated, with consequent reduction of alveolar and arterial $\mathrm{CO}_{2}$ pressure, $\mathrm{PCO}_{2}$; in metabolic alkalosis, however, there has been disagreement as to whether or not there is a corresponding respiratory inhibition, with elevation of $\mathrm{PCO}_{2}$. Evidence that such inhibition does occur has been presented in several reports (1-4); on the other hand, some investigators have found no significant change in $\mathrm{PCO}_{2}$ (5). Opportunity for the collection of further evidence on this question was afforded by a series of studies on the effects of acute metabolic alkalosis induced in human subjects by the infusion of hypertonic sodium bicarbonate solution, approximately $2.3 \mathrm{mEq}$. per kilogram of body weight. The first paper of this series (6) described the ionic transfers as observed in arterial or cutaneous blood, and calculated for extracellular and other body fluid compartments, including the volume of distribution of the excess sodium bicarbonate. The plasma acid-base data from these experiments readily permit the calculation of arterial $\mathrm{PCO}_{2}$, before, during, and for two hours following the infusion. We consider the changes in calculated arterial $\mathrm{PCO}_{2}$ to represent the most reliable index of respiratory changes, because this sampling method produced the least disturbance to respiration. However, we are also reporting in this, the second paper of the series, results of additional experiments in which alveolar $\mathrm{PCO}_{2}$, total pulmonary ventilation, and respiratory

1 Laboratory facilities were aided by grants from the American Philosophical Society, the Life Insurance Medical Research Fund, the U. S. Public Health Service (grant H-405) and the C. Mahlon Kline Fund for Developments in the Department of Medicine.

2 Present address : 501 Boylston Street, Boston 17, Massachusetts.

3 Present address : Nasson College, Springvale, Maine. output of $\mathrm{CO}_{2}$ were measured. The effects of the infusion on urinary electrolyte excretion and renal hemodynamics are presented in a final paper (7).

Our results indicate that respiration was stimulated during, and depressed following the infusion. This biphasic respiratory response distinguishes sodium bicarbonate from other alkalinizing solutions, such as sodium carbonate and sodium hydroxide. The latter solutions, when given intravenously to dogs, have been shown to produce respiratory inhibition both during and after the infusion $(1,4)$. It will be demonstrated that the initial stimulation of respiration by sodium bicarbonate occurs only during the infusion and is associated with an increased output of $\mathrm{CO}_{2}$.

\section{METHODS}

The subjects, all men, were volunteers in good healts: or convalescent hospital patients. All tests were carried out with the subject supine, at rest, and shielded as far as possible from distracting procedures that might stimulate respiration through apprehension or discomfort. The venipuncture required for the administration of the sodium bicarbonate solution was made 10 minutes or more prior to the actual infusion period, the needle being kept open with a slow drip of 5 per cent glucose in water. A solution of 0.89 molar (7.5 per cent) sodium bicarbonate was used, ${ }^{4}$ with a total dose ranging from 1.36 to $2.50 \mathrm{mEq}$. per kilogram of body weight, the average for most subjects being close to $2.3 \mathrm{mEq}$. per $\mathrm{kg}$. The entire volume of this solution, usually 150 to $200 \mathrm{ml}$., was infused in 10 minutes. No untoward effects were observed as a result of this dose and infusion rate; some subjects noted minor symptoms, such as transient tingling of the skin or a sensation of cold in the infusion arm.

In the experiments involving arterial blood, an indwelling needle was inserted into the femoral artery 30

4 A supply of the sterile solution in ampule form was generously furnished by the Abbott Laboratories. 
to 90 minutes before the first control sample was taken, to allow ample time for the subject to assume a stable level of quiet respiration. The needle was connected via a plastic tube with a stopcock manifold, to which were attached the sampling syringes and a wash-out syringe containing a saline-heparin solution. Each sampling syringe was prepared with a measured amount of the heparin solution to eliminate air-containing dead space and serve as an anticoagulant. Blood samples were stored in the syringes, in a beaker of cracked ice, until samples were withdrawn for centrifuging or $\mathrm{pH}$ determination. The handling of blood for centrifuging and separation of plasma was accomplished by a "virtual anaerobic" technic (8). In this technic the use of oil or paraffin is avoided entirely, at the expense of about 1 in 15 seconds' exposure of the sample to air during the filling of the centrifuge tube or withdrawal of the plasma sample. The effect of such exposure on $\mathrm{pH}$ and plasma $\mathrm{CO}_{2}$ content is extremely small (8) : a mean decrease of 0.005 for the former and $0.1 \mathrm{mM}$ per $\mathrm{L}$. for the latter. The resultant effect on calculated arterial $\mathrm{PCO}_{2}$ is nil.

The total $\mathrm{CO}_{2}$ concentration of plasma was measured manometrically (9); $\mathrm{pH}$ of "whole blood" (actually, plasma $\mathrm{pH}$ ) was determined either by a photocolorimetric method (8) in the Klett-Summerson filter photometer, or by means of a Cambridge Research Model glass electrode and $\mathrm{pH}$ meter. Readings were carried out at $37^{\circ}$ C. (photocolorimetric), or at room temperature (glass electrode), with Rosenthal's correction of -0.0147 per degree Centigrade temperature difference to obtain $\mathrm{pH}$ at $37^{\circ}$ C. (10). The validity of the colorimetric $\mathrm{pH}$ determination or its photometric adaptation appears to be well substantiated for human blood or plasma when the readings are made at $37^{\circ}$ to $38^{\circ} \mathrm{C}$. $(8,11-13)$. In our hands the standard error of the mean photocolorimetric $\mathrm{pH}$ in triplicate $0.1-\mathrm{ml}$. aliquots was \pm 0.0051 , and of the mean glass electrode $\mathrm{pH}$ in duplicate $1-\mathrm{ml}$. aliquots (employed only in two experiments), approximately \pm 0.01 . The standard error of the mean plasma $\mathrm{CO}_{2}$ determina- tion, for duplicate, $0.2-\mathrm{ml}$. aliquots, was $\pm 0.11 \mathrm{mM}$ per L. Chemical methods for factors other than $\mathrm{pH}$ and $\mathrm{CO}_{2}$ content were the same as those described previously (6).

From the $\mathrm{pH}$ and plasma total $\mathrm{CO}_{2}$ concentration the $\mathrm{PCO}_{2}$ was calculated by the Henderson-Hasselbalch equation, in which $\mathrm{pK}_{1}^{\prime}$ was assigned the value 6.10 , and $\mathrm{fCO}_{2}$, the solubility factor for dissolved $\mathrm{CO}_{2}$ gas plus carbonic acid at $37^{\circ} \mathrm{C}$. in plasma, the value $0.0314 \mathrm{mM}$ per L. per mm. $\mathrm{PCO}_{2}(13-16)$ :

$$
\mathrm{pH}=\mathrm{pK}_{1}^{\prime}+\log \frac{\left(\mathrm{CO}_{2}\right)_{p}-\mathrm{f}_{\mathrm{CO}_{2} \mathrm{P}_{\mathrm{CO}_{2}}}}{\mathrm{f}_{\mathrm{CO}_{2} \mathrm{P}_{\mathrm{CO}_{2}}}}
$$

These acid-base data, in conjunction with the hemoglobin concentration, were also used to obtain the whole blood buffer base concentration by means of a nomogram devised for that purpose (17). The buffer base, $49 \pm 3$ $\mathrm{mEq}$. per $\mathrm{L}$. in normal blood, is the cation equivalent to the sum of all buffer anions and is a convenient index of the metabolic or electrolyte factor in the acid-base balance of blood, independent of the chemical effects of changing respiration and $\mathrm{PCO}_{2}$.

Nine sodium bicarbonate experiments were carried out in which arterial blood was sampled as described above (Group A). Three similar control experiments (Group D) were performed with 5 per cent glucose, 0.9 per cent sodium chloride, or 25 per cent mannitol substituted as a neutral solution in place of the sodium bicarbonate. Respiratory measurements were carried out in two other groups of subjects. End-expiratory "alveolar" air was collected from 5 subjects (Group B) by means of a semiautomatic sampling device (18) and analyzed for $\mathrm{CO}_{2}$ with the Scholander gas analyzer (19); three of these were carried out in combination with arterial blood sampling. Expired air collections were made in another group of 5 subjects (Group C), and data were obtained for respiratory rate, tidal volume, total ventilation, and output of $\mathrm{CO}_{2}$. To a large extent respiratory measurements were avoided in the Group A subjects, because

TABLE I

Subject S. R.-arterial blood and alveolar air data *

\begin{tabular}{|c|c|c|c|c|c|c|c|c|c|c|}
\hline \multirow[b]{3}{*}{ Sample } & \multirow[b]{3}{*}{ Timet } & \multicolumn{7}{|c|}{ Observed data } & \multirow{2}{*}{\multicolumn{2}{|c|}{$\frac{\text { Calculated }}{\text { Arterial blood }}$}} \\
\hline & & \multicolumn{6}{|c|}{ Arterial blood } & \multirow{2}{*}{$\frac{\text { Alv. air }}{\mathrm{PcO}_{2}}$} & & \\
\hline & & $\begin{array}{l}\text { Hemo- } \\
\text { globin }\end{array}$ & $\begin{array}{c}\text { Cell } \\
\text { volume }\end{array}$ & pH & $\begin{array}{l}\text { Plasma } \\
\mathrm{CO}_{2}\end{array}$ & $\begin{array}{l}\text { Plasma } \\
\mathrm{Na}\end{array}$ & $\begin{array}{c}\text { Plasma } \\
\text { Cl }\end{array}$ & & $\mathrm{POO}_{2}$ & $\left(\mathrm{BB}^{+}\right)_{b}$ \\
\hline $\begin{array}{l}1 \\
2\end{array}$ & $\begin{array}{l}\min . \\
-20 \\
-16\end{array}$ & $\begin{array}{c}m M / L . \\
9.3 \\
9.2\end{array}$ & $\begin{array}{c}\% \\
47.5 \\
47.5\end{array}$ & $\begin{array}{l}7.38 \\
7.37\end{array}$ & $\begin{array}{c}m M / L \\
27.7 \\
27.7\end{array}$ & $\begin{array}{c}m E q . / L . \\
142 \\
141\end{array}$ & $\begin{array}{c}m E q . / L \\
104.6 \\
107.3\end{array}$ & $\begin{array}{l}m m . \\
41.7 \\
44.0\end{array}$ & $\begin{array}{c}m m . \\
45 \\
46\end{array}$ & $\begin{array}{c}m E q . / L \\
49.0 \\
48.5\end{array}$ \\
\hline $\begin{array}{l}3 \\
4\end{array}$ & $\begin{array}{l}-7 \\
-0.5\end{array}$ & $\begin{array}{l}8.6 \\
8.5\end{array}$ & $\begin{array}{l}45.0 \\
44.5\end{array}$ & $\begin{array}{l}7.44 \\
7.48\end{array}$ & $\begin{array}{l}34.8 \\
38.5\end{array}$ & $\begin{array}{l}144 \\
146\end{array}$ & $\begin{array}{l}103.9 \\
103.0\end{array}$ & $\begin{array}{l}47.2 \\
47.0\end{array}$ & $\begin{array}{l}50 \\
51\end{array}$ & $\begin{array}{l}55.5 \\
60.0\end{array}$ \\
\hline $\begin{array}{l}5 \\
6 \\
7 \\
8\end{array}$ & $\begin{array}{l}+5 \\
+10 \\
+22 \\
+60\end{array}$ & $\begin{array}{l}8.8 \\
8.8 \\
9.0 \\
9.0\end{array}$ & $\begin{array}{l}43.0 \\
43.0 \\
43.0 \\
44.5\end{array}$ & $\begin{array}{l}7.44 \\
7.43 \\
7.41 \\
7.40\end{array}$ & $\begin{array}{l}35.3 \\
34.0 \\
32.7 \\
31.5\end{array}$ & $\begin{array}{l}145 \\
142 \\
142 \\
142\end{array}$ & $\begin{array}{l}101.9 \\
104.6 \\
103.1 \\
103.1\end{array}$ & $\begin{array}{l}46.7 \\
46.2 \\
46.3 \\
46.2\end{array}$ & $\begin{array}{l}51 \\
50 \\
50 \\
49\end{array}$ & $\begin{array}{l}\mathbf{5 6 . 0} \\
\mathbf{5 5 . 0} \\
\mathbf{5 3 . 0} \\
\mathbf{5 2 . 5}\end{array}$ \\
\hline
\end{tabular}

* IV infusion of $156 \mathrm{mEq}$. of $\mathrm{NaHCO}_{3}$ (175 ml. of 7.5 per cent solution) from -11.5 to 0 minutes. $\dagger$ Time referred to end of infusion as 0 minutes.

¥ Whole blood buffer base concentration. 
TABLE II

Subject S. R. Trespiratory data (second infusion) *

\begin{tabular}{|c|c|c|c|c|c|c|c|}
\hline \multirow[b]{2}{*}{ Period } & & \multicolumn{3}{|c|}{ Mean respiratory } & \multirow[b]{2}{*}{$\begin{array}{l}\text { Expired air } \\
\mathrm{CO}_{2} \text { content }\end{array}$} & & \\
\hline & Time† & Rate & $\begin{array}{l}\text { Tidal } \\
\text { vol. }\end{array}$ & $\begin{array}{l}\text { Total } \\
\text { vent. }\end{array}$ & & \multicolumn{2}{|c|}{ Rate of $\mathrm{CO}_{2}$ elim. } \\
\hline $\begin{array}{l}1 \\
2 \\
3\end{array}$ & $\begin{array}{l}\min . \\
-68.0 \text { to }-60.0 \\
-49.0 \text { to }-41.0 \\
-25.0 \text { to }-16.5\end{array}$ & $\begin{array}{c}\text { per } \min . \\
9.7 \\
11.7 \\
10.8\end{array}$ & $\begin{array}{l}m l . \ddagger \\
525 \\
490 \\
460\end{array}$ & $\begin{array}{c}\text { L. } / \min . \mp \\
5.1 \\
5.7 \\
5.0\end{array}$ & $\begin{array}{c}\% \\
4.13 \\
3.57 \\
3.90\end{array}$ & $\begin{array}{l}\text { ml. } / \text { min. } 8 \\
178 \\
174 \\
166\end{array}$ & $\begin{array}{c}\operatorname{mM} / \min . \\
8.0 \\
7.8 \\
7.5\end{array}$ \\
\hline 4 & -8.0 to $\quad 0.0$ & 11.5 & 535 & 6.2 & 4.61 & 240 & 10.8 \\
\hline $\begin{array}{l}5 \\
6 \\
7\end{array}$ & $\begin{array}{l}+3.0 \text { to }+11.0 \\
+14.0 \text { to }+22.0 \\
+49.0 \text { to }+57.0\end{array}$ & $\begin{array}{l}9.2 \\
8.2 \\
8.2\end{array}$ & $\begin{array}{l}520 \\
570 \\
580\end{array}$ & $\begin{array}{l}4.8 \\
4.7 \\
4.8\end{array}$ & $\begin{array}{l}4.31 \\
4.47 \\
4.72\end{array}$ & $\begin{array}{l}175 \\
177 \\
190\end{array}$ & $\begin{array}{l}7.9 \\
8.0 \\
8.5\end{array}$ \\
\hline
\end{tabular}

* IV infusion of $156 \mathrm{mEq}$. of $\mathrm{NaHCO}_{3}(175 \mathrm{ml}$. of 7.5 per cent solution) during period 4.

+ Time referred to end of infusion as 0 minutes.

\pm ATPS $\left(758 \mathrm{~mm}\right.$. and $26.5^{\circ} \mathrm{C}$.).

8 STPD.

the necessary sampling procedures would have disturbed the base-line respiration and thus vitiated the unique advantage of the arterial technic.

\section{RESULTS}

Complete data for a single subject, S. R., on arterial blood and alveolar air are given in Table I; similar respiratory measurements are shown in Table II. These are representative detailed results from the three groups of experiments, A, B, and $C .{ }^{5}$ The maximum acid-base changes in arterial blood are seen to occur at the end of the infusion: rise in $\mathrm{pH}$, whole blood buffer base, and concentrations of sodium, total $\mathrm{CO}_{2}$, and bicarbonate in plasma. These changes characterize a primary metabolic alkalosis of the sodium excess type. The fall in hemoglobin and plasma chloride concentrations was a dilution effect, due to the volume of the infused solution and its hypertonic character, as a result of which water was drawn from tissue cells. There was an initial rapid recovery rate in the first half-hour, and a slower one thereafter. We have estimated that at the end of two hours an average of 51 per cent of the dose can still be accounted for in red cells and "extracellular fluid," 27 per cent has been excreted in the urine, and the remaining 22 per cent has apparently penetrated "intracellular fluid" (6). The maximum rise in calculated arterial and al-

5 Nine of the experiments in Groups A and D were continued for the full 2 hours after the infusion. Complete arterial blood data for 6 other subjects in Group A may be found in the preceding paper (6). veolar $\mathrm{PCO}_{2}$ also occurred at the end of the infusion. The total ventilation rose during the infusion and subsequently fell. The rate of pulmonary $\mathrm{CO}_{2}$ output was sharply elevated during the infusion, then returned to its pre-infusion level.

The individual curves for each subject, calculated as serial differences from the mean control levels of $\mathrm{pH}, \mathrm{PCO}_{2}$, and respiratory factors, are given in Figures 1 to 3 . The response of the 9

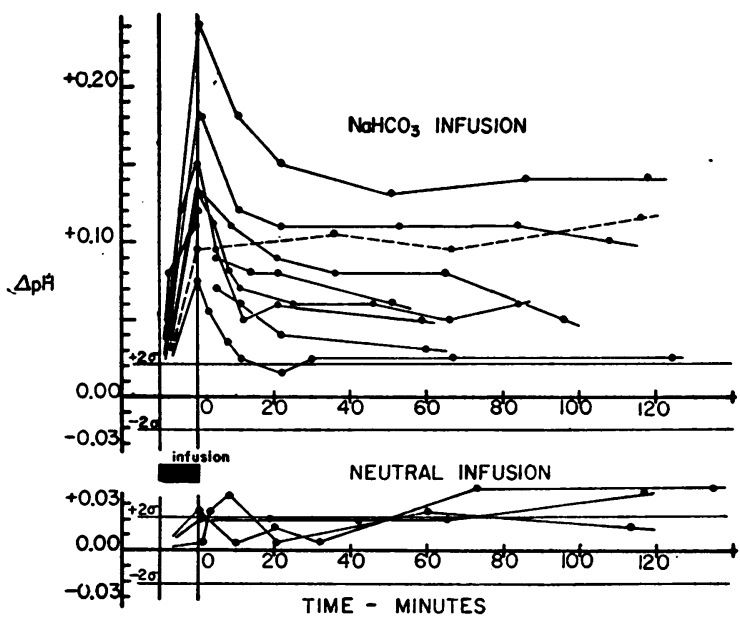

Fig. 1. Changes in Arterial Blood pH from Mean Control Levels Exhibited by Nine Normal Subjects Following the Infusion of Hypertonic Sodium Bicarbonate (Upper Portion of Graph) and Similar Changes Exhibited by Three Normal Subjects FolLowing the Infusion of Neutral Solutions (Lower Portion OF Graph)

Mean control values are given in Table III. The dashed curve represents subject $R$. L., who had very low control pH values. 


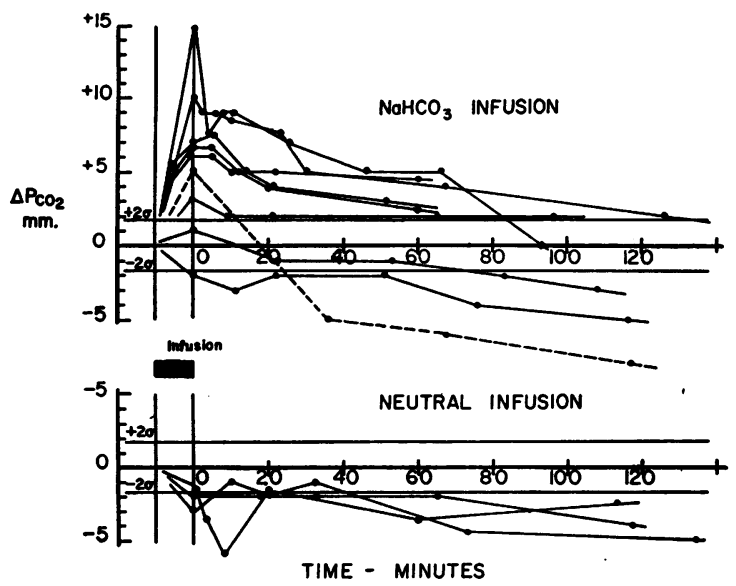

Fig. 2. Changes in Calculated Arterial $\mathrm{PCO}_{2}$ from Mean Control Levels Exhibited by Nine Normal Subjects Following the Infusion of Hypertonic Sodium Bicarbonate (Upper Portion of Graph) and Smilar Changes Exhibited by Three Normal SubJects Following the Infusion of Neutral Solutions (Lower Portion of Graph)

Mean control values are given in Table III. The dashed curve represents subject $R$. L., who had very high control $\mathrm{PCO}_{2}$ values.

subjects of Group A is compared with that of the 3 subjects receiving neutral infusion, with respect to $\mathrm{pH}$ in Figure 1, and arterial $\mathrm{PCO}_{2}$ in Figure 2. The control subjects maintained a nearly constant bicarbonate concentration, and the upward trend in $\mathrm{pH}$ was therefore associated with a downward trend in calculated arterial $\mathrm{PCO}_{2}$. Although no respiratory measurements were carried out in the neutral infusion experiments, the fall in $\mathrm{PCO}_{2}$
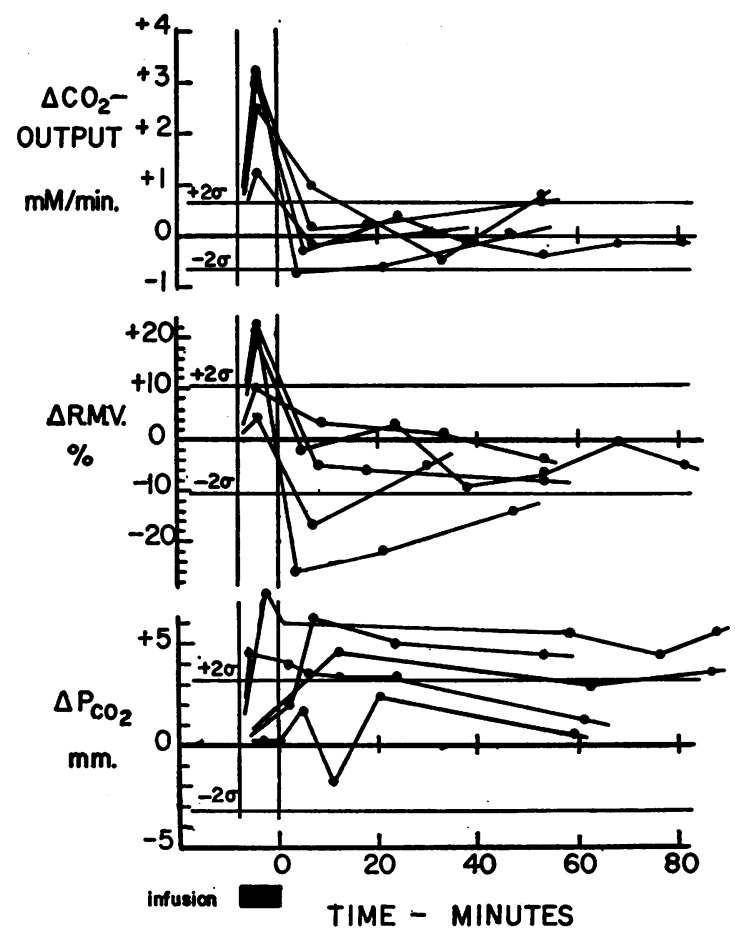

Fig. 3. Changes from Control Values Exhibited by Groups of Five Normal Subjects Following the INFUSION OF HYPERTONIC SODIUM BICARBonAte, WITH REspect to Respiratory Elimination of $\mathrm{CO}_{2}$ (UPPER), Respiratory Minute Volume (Middle), aNd EndExpiratory, "Alveolar" $\mathrm{PCO}_{2}$ (Lower)

Mean control values are given in Table III.

implies an increase in total ventilation. In the sodium bicarbonate experiments the rise in alveolar $\mathrm{PCO}_{2}$, the transient rise in $\mathrm{CO}_{2}$ output during the infusion, and the generally biphasic re-

TABLE III

Mean control data and dose of $\mathrm{NaHCO}_{3}$

\begin{tabular}{|c|c|c|c|c|c|c|}
\hline Group & $\begin{array}{c}\text { No. of } \\
\text { subjects }\end{array}$ & $\begin{array}{c}\text { Dose of } \\
\mathrm{NaHCO}_{3}\end{array}$ & Factor & Unit & Mean & S.D. \\
\hline $\mathbf{A}$ & 9 & $\begin{array}{c}2.29 \\
\mathrm{mEq} \cdot / \mathrm{Kg} .\end{array}$ & $\begin{array}{c}\left(\mathrm{CO}_{2}\right)_{\mathrm{p}} \\
\mathrm{pH} \\
\text { Art. } \mathrm{PCO}_{2} \\
\left(\mathrm{BB}^{+}\right)_{\mathrm{b}}\end{array}$ & $\begin{array}{l}\mathrm{mM} / \mathrm{L} . \\
\mathrm{mm} . \mathrm{Hg} \\
\mathrm{mEq} \cdot / \mathrm{L} .\end{array}$ & $\begin{array}{l}26.8 \\
7.37^{*} \\
45.0 \dagger \\
47.7\end{array}$ & $\begin{array}{c} \pm 0.90 \\
0.036^{*} \\
3.68 \dagger \\
1.61\end{array}$ \\
\hline B & 5 & 2.15 & Alv. $\mathrm{P}_{\mathrm{CO}_{2}}$ & $\mathrm{~mm} . \mathrm{Hg}$ & 39.9 & 2.81 \\
\hline C & 5 & 1.61 & $\begin{array}{l}\text { Tot. vent. } \\
\mathrm{CO}_{2} \text { output }\end{array}$ & $\begin{array}{l}\text { L./min. ATPS } \\
\mathrm{mM} / \mathrm{min} .\end{array}$ & $\begin{array}{l}6.28 \\
9.15\end{array}$ & $\begin{array}{l}1.19 \\
0.88\end{array}$ \\
\hline D & 3 & $\begin{array}{c}0 \\
\text { (Neutral } \\
\text { infusions) }\end{array}$ & $\begin{array}{c}\left(\mathrm{CO}_{2}\right)_{\mathrm{p}} \\
\mathrm{pH} \\
\text { Art. } \mathrm{P}_{\mathrm{CO}_{2}} \\
\left(\mathrm{BB}^{+}\right)_{\mathrm{b}}\end{array}$ & $\begin{array}{c}\mathrm{mM} / \mathrm{L} . \\
\mathrm{mm} . \mathrm{Hg} \\
\mathrm{mEq} \cdot / \mathrm{L} .\end{array}$ & $\begin{array}{c}27.8 \\
7.37 \\
46.2 \\
48.0\end{array}$ & $\begin{array}{l}1.90 \\
0.015 \\
1.02 \\
1.95\end{array}$ \\
\hline
\end{tabular}

* Omitting subject R. L., pH $7.38 \pm 0.023$.

† Omitting subject R. L., arterial $\mathrm{PoO}_{2} 43.9 \pm 1.38$. 
TABLE IV

Significance of mean changes from control levels

\begin{tabular}{|c|c|c|c|c|c|c|}
\hline \multirow{2}{*}{$\begin{array}{l}\text { Interval, } \\
\text { control per. } \\
\text { to period of }\end{array}$} & \multirow[b]{2}{*}{ Factor } & \multirow{2}{*}{$\frac{\text { Group A }}{\text { Art. } \triangle \mathrm{Pcos}}$} & \multirow{2}{*}{$\frac{\text { Group B }}{\text { Alv. } \triangle \text { Pcos }^{\prime}}$} & \multicolumn{2}{|c|}{ Group C } & \multirow{2}{*}{$\frac{\text { Group } D^{*}}{\text { Art. } \Delta \text { Pcos }}$} \\
\hline & & & & $\Delta$ Tot. vent. & $\triangle \mathrm{CO}_{2}$ output & \\
\hline Infusion & $\begin{array}{c}\text { Mean diff. } \\
\text { S.E. } \\
\mathrm{t}=\Delta / \mathrm{S} . \mathrm{E} . \\
\text { D.F. } \\
\text { P† }\end{array}$ & $\begin{array}{c}m m . H g \\
+4.5 \ddagger \\
\pm 0.29 \\
15 \\
2 \\
<0.01\end{array}$ & $\begin{array}{c}m m . \mathrm{Hg} \\
+4.0 \\
\pm 2.25 \\
1.78 \\
2 \\
0.3\end{array}$ & $\begin{array}{l}\text { \% control } \\
+14 \\
\pm 3.70 \\
3.78 \\
4 \\
0.02\end{array}$ & $\begin{array}{c}\text { \% control } \\
+29 \\
\pm 4.78 \\
6.06 \\
4 \\
<0.01\end{array}$ & $m m . H g$ \\
\hline $\begin{array}{l}\text { Early post- } \\
\text { infusion } \\
\text { ( } 0 \text { to } 55 \mathrm{~min} .)\end{array}$ & $\begin{array}{c}\text { Mean diff. } \\
\text { S.E. } \\
\mathrm{t}=\Delta / \mathrm{S} . \mathrm{E} . \\
\text { D.F. } \\
\text { P }\end{array}$ & $\begin{array}{l}+3.5 \\
\pm 1.25 \\
2.80 \\
8 \\
0.03\end{array}$ & $\begin{array}{l}+3.8 \\
\pm 0.95 \\
4.05 \\
4 \\
0.02\end{array}$ & $\begin{array}{c}-9.3 \\
\pm 3.62 \\
2.60 \\
4 \\
0.06\end{array}$ & $\begin{array}{c}0 \\
\pm 4.61 \\
0 \\
4 \\
\text { not sign. }\end{array}$ & $\begin{array}{c}-2.3 \\
+0.41 \\
5.72 \\
2 \\
0.04\end{array}$ \\
\hline $\begin{array}{c}\text { Late post- } \\
\text { infusion } \\
\text { (55 to } 127 \mathrm{~min} .)\end{array}$ & $\begin{array}{c}\text { Mean diff. } \\
\text { S.E. } \\
\mathrm{t}=\Delta / \mathrm{S} . \mathrm{E} . \\
\text { D.F. } \\
\text { P. }\end{array}$ & $\begin{array}{c}+0.3 \\
\pm 1.21 \\
0.25 \\
8 \\
>0.5\end{array}$ & & & & $\begin{array}{c}-3.7 \\
\pm 0.62 \\
5.97 \\
2 \\
0.03\end{array}$ \\
\hline
\end{tabular}

* Group D-received neutral infusion instead of $\mathrm{NaHCO}_{2}$.

$\dagger P$ values taken from "Student's" $t$ test, for calculated value of $t$ and number of degrees of freedom, D.F. $¥$ Significant differences $(P \gtrless 0.05)$ italicized.

sponse of total ventilation (results from Groups $\mathrm{B}$ and $\mathrm{C}$ ) are shown in Figure 3. The horizontal lines above and below the base-line of 0 change in Figures 1 to 3 represent 95 per cent confidence limits of the intra-individual variability. For each factor the standard deviation, $\sigma$, of all control observations about the respective individual means was calculated. Confidence limits were set at $\pm 2 \sigma$, and were found to be $\pm 0.46 \mathrm{mM}$ per $\mathrm{L}$. for plasma $\mathrm{CO}_{2}$ concentration, \pm 0.022 for $\mathrm{pH}$, $\pm 1.72 \mathrm{~mm}$. of $\mathrm{Hg}$ for calculated arterial $\mathrm{PCO}_{2}$, $\pm 0.80 \mathrm{mEq}$. per L. for whole blood buffer base, $\pm 3.22 \mathrm{~mm}$. of $\mathrm{Hg}$ for alveolar $\mathrm{PCO}_{2}, \pm 0.78 \mathrm{~L}$. per min. ATPS for total ventilation, and $\pm 0.54 \mathrm{mM}$ per min. for $\mathrm{CO}_{2}$ output. The control observations of Groups A and D were pooled to give a common set of confidence limits.

It is evident from Figures 1 to 3 that the changes in arterial $\mathrm{pH}$ and $\mathrm{CO}_{2}$ output were consistent in all sodium bicarbonate experiments, and uniformly significant on the basis of the confidence limits of control variability. However, in a minority of tests the $\mathrm{PCO}_{2}$ was not significantly elevated, and the total ventilation was not significantly depressed following the infusion. In the second hour after the infusion, 3 of the subjects in Group A exhibited a significant decrease in arterial $\mathrm{PCO}_{2}$ (Figure 2). This response is similar to the one shown by the subjects receiving neutral infu- sions. The dashed curve in Figures 1 and 2 is that of a subject having the extremely high control $\mathrm{PCO}_{2}$ of $54 \mathrm{~mm}$. of $\mathrm{Hg}$.

The significance of mean changes in the various groups was evaluated by the usual $t$ test, the control values being compared with those obtained (a) during the infusion, (b) during the early postinfusion period, from 0 to 55 minutes after the end of the infusion, and (c) during the late postinfusion period. Table III contains mean values, with standard deviation, for the respiratory and acid-base factors in each of the four groups of experiments, as well as the mean dose of sodium bicarbonate. The results in Table IV include sets of mean differences from the control level, the standard error of each difference, S.E., the $t$ value (ratio of mean difference to its S.E.), and the probability, $p$, that the difference is due to chance. The rise in arterial and alveolar $\mathrm{PCO}_{2}$ in the early post-infusion period is seen to be significant ( $p<0.05)$; during the infusion only the arterial $\mathrm{PCO}_{2}$ was significantly elevated, but the number of observations was small. The 14 per cent elevation of total ventilation during the infusion was significant, but the 9.3 per cent decrease in the early post-infusion just failed to attain the 95 per cent level of significance with a $p$ of 0.06 . The increase in $\mathrm{CO}_{2}$ output during the infusion was highly significant, and the mean change was nil for the early 
post-infusion period. In the group of subjects given neutral infusions the arterial $\mathrm{PCO}_{2}$ was significantly decreased in both the early and late post-infusion periods.

\section{DISCUSSION}

These results exhibit the biphasic character of the respiratory response to sodium bicarbonate infusion in man : an initial increase in total ventilation, indicating a stimulation to respiration, during the infusion; and a decrease in total ventilation, indicating respiratory inhibition, following the infusion. This biphasic character is a unique feature of sodium bicarbonate administration; other alkalinizing solutions, such as sodium hydroxide and sodium carbonate, evoke a decrease in total ventilation both during and after the infusion (1, 4). The initial stimulation of respiration by sodium bicarbonate solutions has been reported in experiments on dogs by Gesell, Krueger, Gorham, and Bernthal (1), Bernthal (3), and Hesser (4).

The difference in action of sodium bicarbonate as compared with other alkalinizing solutions is related to the chemical reactions that occur in blood during the infusion. Highly alkaline solutions produce a relatively marked rise in $\mathrm{pH}$ and transient fall in $\mathrm{H}_{2} \mathrm{CO}_{3}$ and therefore the $\mathrm{PCO}_{2}$ of admixed blood:

$$
\begin{aligned}
\mathrm{Na}^{+}+\mathrm{OH}^{-}+\mathrm{HBuf} & \rightarrow \mathrm{Na}^{+}+\mathrm{Buf}^{-}+\mathrm{H}_{2} \mathrm{O} \\
\mathrm{Na}^{+}+\mathrm{OH}^{-}+\mathrm{H}_{2} \mathrm{CO}_{3} & \rightarrow \mathrm{Na}^{+}+\mathrm{HCO}_{3}^{-}+\mathrm{H}_{2} \mathrm{O}
\end{aligned}
$$

The symbol Buf- represents non-bicarbonate buffer anion, chiefly hemoglobin and plasma protein anion, and HBuf the corresponding undissociated buffer acid. ${ }^{\circ}$ In the case of the rather weakly alkaline sodium bicarbonate solution, most of the added $\mathrm{Na}^{+}$and $\mathrm{HCO}_{8}-$ ions simply increase the initial concentrations of these ions in blood. However, to some extent the following reactions occur, the dehydration of $\mathrm{H}_{2} \mathrm{CO}_{3}$ being catalyzed by the enzyme carbonic anhydrase in red cells:

$$
\begin{gathered}
\mathrm{Na}^{+}+\mathrm{HCO}_{3}^{-}+\mathrm{HBuf} \rightarrow \mathrm{Na}^{+}+\mathrm{Buf}^{-}+\mathrm{H}_{2} \mathrm{CO}_{3} \\
\mathrm{H}_{2} \mathrm{CO}_{3} \underset{\text { anhydrase }}{\stackrel{\text { carbonic }}{\longrightarrow}} \mathrm{H}_{2} \mathrm{O}+\mathrm{CO}_{2} \uparrow
\end{gathered}
$$

6 In actual fact, there is little penetration of excess $\mathrm{Na}^{+}$with $\mathrm{OH}^{-}$or $\mathrm{HCO}_{3}^{-}$into the red cell. Exchange of plasma $\mathrm{HCO}_{3}^{-}$for a smaller amount of cell $\mathrm{Cl}^{-}$has the same effect in permitting the red cell $\mathrm{HHbO}_{2}$ to carry out its share of the buffering action.
The vertical arrow symbolizes the volatile nature of the excess $\mathrm{CO}_{2}$ thus formed, since, under ordinary circumstances, it will bubble off from a blood-mixture in a beaker, or appear as nonmetabolic $\mathrm{CO}_{2}$ in expired air. This is the explanation for the rise in $\mathrm{CO}_{2}$ output in expired air during the infusion period (Figure 3 ). For each millimole of excess $\mathrm{H}_{2} \mathrm{CO}_{3}$ or $\mathrm{CO}_{2}$ produced in this reaction a milliequivalent of buffer anion, Buf-, is also formed. It is therefore possible to calculate the quantity of non-metabolic $\mathrm{CO}_{2}$ appearing in expired air during the infusion period from the increase in Buf-, which can, in turn, be calculated from the $\mathrm{pH}$ rise, the titration properties of human blood (16), and the estimated quantity of non-bicarbonate buffers in the whole blood volume, as described in the preceding paper (6). We have made a calculation of this type for the mean result of the Group $\mathrm{C}$ experiments, recognizing that it is an approximation only, since blood studies were not carried out simultaneously in the subjects of this group. The mean $\Delta \mathrm{pH}$ for the nine experiments of Group A was +0.14 , corresponding to a mean dose of $2.29 \mathrm{mEq}$. per kg. of body weight. The value of $\Delta \mathrm{pH}$ estimated for the mean of the five subjects of Group C, with a smaller dose of $1.61 \mathrm{mEq}$. per kg., would therefore be +0.10 . The slope of the titration curve of normal human blood with a hematocrit value of 45 per cent averages $25 \mathrm{mEq}$. per L. per $\mathrm{pH}$ unit $(16,17)$. The blood volume was assumed to be $80 \mathrm{ml}$. per $\mathrm{kg}$. of body weight (20), or a .mean of 6.2 liters for these subjects (average weight $78 \mathrm{~kg}$.). The rise in non-bicarbonate buffer anions, $\triangle \mathrm{Buf}$, was thereby calculated:

$$
\Delta \text { Buf }^{-}=(0.10)(25)(6.2)=16 \mathrm{mEq} .
$$

The mean quantity of excess $\mathrm{CO}_{2}$ collected during the infusion period was $18 \mathrm{mM}$ for the same five subjects, a close agreement, considering the number of assumptions made in the calculation.

Any attempt to postulate a mechanism for the respiratory stimulation during sodium bicarbonate infusion leads to manifold and complex considerations that lie beyond the scope of this paper. Available evidence reveals only two points of difference between the stimulation seen during infusion of sodium bicarbonate and the inhibition during the infusion of other alkalinizing solutions : the 
rise in $\mathrm{CO}_{2}$ output and the rise in $\mathrm{PCO}_{2}$ of venous blood, at least locally where blood is mixed with sodium bicarbonate infusion, as contrasted with the decrease in these variables when non-bicarbonate alkalinizers are administered by vein. The $\mathrm{PCO}_{2}$ of arterial blood (supplying both the carotid body chemo-receptors and the cells of the respiratory center) is elevated regardless of the type of alkalinizing solution being infused.

In the first hour after the end of the infusion our observations conform to the usual concept of secondary respiratory inhibition in any primary metabolic alkalosis: decrease in total ventilation and increase in arterial and alveolar $\mathrm{PCO}_{2}$, associated with the rise in blood $\mathrm{pH}$, and bicarbonate and buffer base concentrations. Once it has been established that the $\mathrm{CO}_{2}$ output of expired air does not differ from the control level (Table IV), a significant elevation of calculated arterial $\mathrm{PCO}_{2}$ must be associated, through the alveolar equation, with a significant fall in alveolar ventilation, hence a respiratory inhibition. We regard this as sufficient evidence for a significant average respiratory response, even though the observed decrease in total ventilation was found to have a $p$ value between 0.05 and 0.06 .

Although satisfactory levels of significance were established for the changes of respiratory inhibition in the first hour after the infusion, there was a wide scatter of individual response in the second hour. In some individuals with primary metabolic alkalosis ventilation is not decreased, and the $\mathrm{PCO}_{2}$ of arterial, or its equivalent, cutaneous blood is not elevated. The problem is further complicated when clinical patients are studied: control observations are usually not available, and the upper limit of normal $\mathrm{PCO}_{2}$ appears to be higher than generally supposed, if physiological variations and truly basal conditions of respiration are taken into account (Table III, references 21-23). Even if the too low conventional limit of $45 \mathrm{~mm}$. of $\mathrm{Hg}$ is used as this dividing line in arterial or cutaneous blood, the incidence of $\mathrm{PCO}_{2}$ values exceeding $45 \mathrm{~mm}$. is found to be only 26 per cent in one series of patients with metabolic alkalosis (24). Thus it is not surprising that the existence of a secondary respiratory inhibition in this acidbase disturbance should have been denied by West and Rapoport (5). However, the experimental evidence of these authors, obtained on three dogs, is open to the criticism that conclusions were based on the analysis of venous blood, in which the $\mathrm{PCO}_{2}$ is a much less reliable index of respiration than it is in arterial or cutaneous blood. At least one of the papers cited by West and Rapoport in support of their view actually confirms the presence of a respiratory inhibition. This is the work of Shock and Hastings, involving serial cutaneous blood observations up to seven hours after the oral ingestion of sodium bicarbonate by normal human subjects (2). From supplementary protocols, referred to but not printed in full in Shock and Hastings' paper, we have calculated that the mean rise in $\mathrm{PCO}_{2}$ was highly significant $(p<0.01)$ in nine such experiments, during the period from one-half to three hours after the maximum effect on blood bicarbonate.

Other factors that contribute to the difficulty of detecting and measuring such a small inhibitory effect are the ease with which respiration is stimulated by psychic and other extraneous stimuli $(25,26)$, and the influence of the experimental sampling procedure on respiration. The effect of both factors is almost invariably to stimulate respiration, increase total ventilation, and thus lower arterial $\mathrm{PCO}_{2}$. In experimental tests this influence is mediated through apprehension and discomfort incident to the sampling procedure or other aspects of the experiment, or through the increase in physiological dead space introduced by most gas sampling devices that do not require the cooperation of the subject. As confirmed in trials of our own, the alveolar $\mathrm{PCO}_{2}$ of subjects breathing naturally is higher than it is when expired air or alveolar air is collected by such devices. Even with the Haldane-Priestley method of sampling alveolar air respiration is disturbed by the forced expiration for as long as 10 minutes. These were the considerations that led us to select the calculated arterial $\mathrm{PCO}_{2}$ as the principal index of respiratory activity, because the arterial blood samples could be obtained at will, without any detectable disturbance to the subject.

Despite these interfering factors tending to stimulate respiration, it was possible to demonstrate a significant inhibitory response for a group of normal subjects under our conditions of experimental metabolic alkalosis. A similar response has been found by others in some but not 
all individuals with this type of acid-base disturbance $(2,24,27,28)$. We therefore regard decrease in total ventilation and elevation of $\mathrm{PCO}_{2}$ as the characteristic secondary changes in any kind of metabolic alkalosis, clinical or experimental. Failure to observe such an inhibition may be due to extraneous stimuli, to the special circumstance of infusing sodium bicarbonate solution, or to the coexistence of a primary respiratory alkalosis, such as might be seen in a dyspneic patient with congestive heart failure, given prolonged treatment with mercurial diuretics (29).

\section{SUMMARY}

1. In different groups of normal human subjects observations were made before, during, and after the infusion of hypertonic sodium bicarbonate solution, of the following acid-base and respiratory factors: (a) arterial $\mathrm{CO}_{2}$ pressure, $\mathrm{PCO}_{2}$, as calculated from $\mathrm{pH}$ and plasma $\mathrm{CO}_{2}$ concentration; (b) end-expiratory alveolar $\mathrm{PCO}_{2}$; (c) total ventilation, from collection of expired air; (d) rate of elimination of $\mathrm{CO}_{2}$ in expired air.

2. During the infusion of sodium bicarbonate, arterial $\mathrm{pH}$, arterial and alveolar $\mathrm{PCO}_{2}$, total ventilation, and rate of elimination of $\mathrm{CO}_{2}$ were significantly increased above control levels. These findings indicate both respiratory stimulation and the intravascular formation of excess carbonic acid, by reaction of the infused bicarbonate ion with the relatively acid protein buffers of blood. Of the various solutions which are biologically alkalinizing only bicarbonate salts produce this initial stimulation.

3. Following the infusion, the rate of $\mathrm{CO}_{2}$ elimination returned to the control level, but arterial $\mathrm{pH}$ was still elevated despite a steady fall toward the control range. In the first hour after the infusion there was a significant elevation of mean arterial and alveolar $\mathrm{PCO}_{2}$ in the groups tested. The corresponding decrease in mean total ventilation was not significant at the 5 per cent level but was significant at the 6 per cent level. These findings indicate a significant degree of secondary respiratory inhibition for the conditions of acute metabolic alkalosis obtaining in these experiments.

4. In three normal subjects given neutral infusions instead of sodium bicarbonate, the arterial $\mathrm{PCO}_{2}$ was significantly decreased from control levels in the first two hours after the infusion. Reasons are presented in support of the view that failure to observe the characteristic respiratory inhibition in some individuals with metabolic alkalosis may be attributed to various types of extraneous or psychic stimulation.

\section{ACKNOWLEDGMENTS}

Grateful acknowledgment is made to Mrs. Dolores Bluemle and Mrs. Claire Tissari for their skilled technical assistance.

\section{REFERENCES}

1. Gesell, R., Krueger, H., Gorham, G., and Bernthal, T., The regulation of respiration. A study of the correlation of numerous factors of respiratory control following intravenous injection of sodium bicarbonate. Am. J. Physiol., 1930, 94, 387.

2. Shock, N. W., and Hastings, A. B., Studies of the acid-base balance of the blood. IV. Characterization and interpretation of displacement of the acid-base balance. J. Biol. Chem., 1935, 112, 239.

3. Bernthal, T., Chemo-reflex control of vascular reactions through the carotid body. Am. J. Physiol., 1938, 121, 1.

4. Hesser, C. M., Central and chemoreflex components in the respiratory activity during acid-base displacements in the blood. Acta physiol. Scandinav., 1949, 18, Supp. 64, 1.

5. West, C. D., and Rapoport, S., Absence of respiratory change or manifest tetany with elevation of plasma $\mathrm{pH}$ produced by bicarbonate administration in dogs. J. Lab. \& Clin. Med., 1950, 36, 428.

6. Singer, R. B., Clark, J. K., Barker, E. S., Crosley, A. P., Jr., and Elkinton, J. R., The acute effects in man of a rapid intravenous infusion of hypertonic sodium bicarbonate solution. I. Changes in acid-base balance and distribution of the excess buffer base. Medicine, 1955, 34, 51.

7. Crosley, A. P., Jr., Clark, J. K., Barker, E. S., Elkinton, J. R., and Singer, R. B., The acute effects in man of a rapid intravenous infusion of hypertonic sodium bicarbonate solution. III. Changes in renal hemodynamics and urinary electrolyte excretion. In preparation.

8. Singer, R. B., Shohl, J., and Bluemle, D. B., Simultaneous determination of $\mathrm{pH}, \mathrm{CO}_{2}$ content and cell volume in $0.1 \mathrm{ml}$. aliquots of cutaneous blood. A modification of the Shock and Hastings technique. Clinical Chemistry, 1955, 1, 287.

9. Van Slyke, D. D., and Sendroy, J., Jr., Carbon dioxide factors for the manometric blood gas apparatus. J. Biol. Chem., 1927, 73, 127.

10. Rosenthal, T. B., The effect of temperature on the $\mathrm{pH}$ of blood and plasma in vitro. J. Biol. Chem., 1948, 173, 25. 
11. Hastings, A. B., and Sendroy, J., Jr., Studies of acidosis. XX. The colorimetric determination of blood $\mathrm{pH}$ at body temperature without buffer standards. J. Biol. Chem., 1924, 61, 695.

12. Myers, V. C., and Muntwyler, E., The colorimetric estimation of the hydrogen ion concentration of blood. J. Biol. Chem., 1928, 78, 243.

13. Van Slyke, D. D., Weisiger, J. R., and Van Slyke, K. K., Photometric measurement of plasma $\mathrm{pH}$. J. Biol. Chem., 1949, 179, 743.

14. Van Slyke, D. D., Sendroy, J., Jr., Hastings, A. B., and Neill, J., Studies of gas and electrolyte equilibria in blood. X. The solubility of carbon dioxide at $38^{\circ}$ in water, salt solution, serum, and blood cells. J. Biol. Chem., 1928, 78, 765.

15. Int. Crit. Tables, 1928, III, 260.

16. Dill, D. B., Edwards, H. T., and Consolazio, W. V., Blood as a physicochemical system. XI. Man at rest. J. Biol. Chem., 1937, 118, 635.

17. Singer, R. B., and Hastings, A. B., An improved clinical method for the estimation of disturbances of the acid-base balance of human blood. Medicine, 1948, 27, 223.

18. Forssander, C. A., and White, C., Mixing of alveolar air with dead space air during expiration. J. Appl. Physiol., 1949, 2, 110.

19. Scholander, P. F., Analyzer for accurate estimation of respiratory gases in one-half cubic centimeter samples. J. Biol. Chem., 1947, 167, 235.

20. Gibson, J. G., 2nd, and Evans, W. A., Jr., Clinical studies of the blood volume. I. Clinical application of a method employing the Azo dye, "Evans blue," and the spectrophotometer. J. Clin. Invest., 1937, 16, 301.

21. Albritton, E. C., Ed., Table 94, Acid-base values, blood and plasma: Man in Standard Values in Blood. Philadelphia, W. B. Saunders, 1952.

22. Shock, N. W., and Hastings, A. B., Studies of the acid-base balance of the blood. III. Variation in the acid-base balance of the blood in normal individuals. J. Biol. Chem., 1934, 104, 585.

23. Mangold, R., Sokoloff, L., Conner, E., Kleinerman, J., Therman, P. G., and Kety, S. S., The effects of sleep and lack of sleep on the cerebral circulation and metabolism of normal young men. J. Clin. Invest., 1955, 34, 1092.

24. Singer, R. B., Unpublished observations.

25. Finesinger, J. E., and Mazick, S. G., The effect of a painful stimulus and its recall upon respiration in psychoneurotic patients. Psychosom. Med., 1940, 2, 333.

26. Stevenson, I., and Ripley, H. S., Variations in respiration and in respiratory symptoms during changes in emotion. Psychosom. Med., 1952, 14, 476.

27. Gamble, J. L., Chemical Anatomy, Physiology and Pathology of Extracellular Fluid. 5th ed., Cambridge, Harvard Univ. Press, 1947.

28. Relman, A. S., and Schwartz, W. B., Unpublished observations.

29. Squires, R. D., Singer, R. B., Moffitt, G. R., Jr., and Elkinton, J. R., The distribution of body fluids in congestive heart failure. II. Abnormalities in serum electrolyte concentration and in acid-base equilibrium. Circulation, 1951, 4, 697. 